УДК 796.011.3:377.8

DOI https://doi.org/10.26661/2663-5925-2020-1-04

\title{
ФОРМУВАННЯ ЗАЦІКАВЛЕНОСТІ СТУДЕНТОК ДО ЗАНЯТЬ ІЗ ФІЗИЧНОГО ВИХОВАННЯ В ЗАКЛАДАХ ВИЩОЇ ОСВІТИ I-II РІВНІВ АКРЕДИТАЦІї ${ }^{1}$
}

\author{
Драпінська Л. М. \\ аспірантка кафедри фітнесу та рекреачіi \\ Львівський державний університет фізичної культури імені Івана Боберського \\ вул. Тадеуша Костюшка, 11, Львів, 79000, Украӥна \\ orcid.org/0000-0001-6470-4849 \\ shypkalyudmila@ukr.net
}

Ключові слова: фізичне виховання, навчальний проиес, шейпінг, студентки, мотивачія.
У статті доведено, що фізичне виховання в закладах вищої освіти I-II рівнів акредитації не виконує свої функції і потребує пошуку нових нетрадиційних засобів і науково обгрунтованих шляхів удосконалення навчального процесу. Усе це зумовлює проведення дослідження, яке передбачає пошук нових засобів удосконалення процесу фізичного виховання студенток, що базується на популярних видах рухової активності. Підвищенню зацікавленості до занять фізичними вправами можуть сприяти нові нетрадиційні засоби і методи. Мета дослідження підвищити ефективність фізичного виховання студенток закладів вищої освіти України I-II рівнів акредитації шляхом застосування шейпінгтехнологій у навчальній формі занять з фізичного виховання. Матеріали $i$ методи. Для вирішення завдань дослідження автором був використаний соціологічний метод шляхом анкетного опитування студенток та методи математичної статистики. Дослідження проводилися в Технологічному коледжі Львівського національного політехнічного університету. Було опитано 40 студенток другого курсу навчання. Результати дослідження. У результаті проведених досліджень з'ясовано, що навчальна форма занять із фізичного виховання закладів вищої освіти потребує пошуку нових методів модернізації навчального процесу і самостійних занять студентів на дозвіллі. Підтверджено уподобання студенток обирати вид фізичних вправ для занять та важливість застосування музичного супроводу занять фізичними вправами. Встановлено, що основними мотивами, що спонукають студенток до занять з фізичного виховання, $\epsilon$ можливість побудови гарної статури, відчуття задоволення від фізичних вправ та можливість зміцнення здоров'я. Однією із причин негативного ставлення студентів до фізичного виховання $є$ низький емоційний фон занять та відсутність можливості вибирати вид рухової активності за вподобанням. Доведено, що заняття шейпінгом під час академічних занять з фізичного виховання сприяли значному зростанню зацікавленості студенток до рухової активності. Висновки. Використання шейпінгтехнологій сприяє підвищенню зацікавленості студенток до навчальної форми занять 3 фізичного виховання. Підвищенню мотивації до занять 3 фізичного виховання можуть сприяти нетрадиційні засоби і методи.

\footnotetext{
${ }^{1}$ Роботу виконано згідно теми НДР кафедри фітнесу та рекреації Львівського державного університету фізичної культури імені Івана Боберського «Технологія залучення населення до оздоровчої рухової активності» на термін 2016-2020 pp.
} 


\title{
FORMATION OF INTEREST OF FEMALE STUDENTS TO PHYSICAL TRAINING CLASSES IN HIGER EDUCAION ESTABLISHMENTS OF THE $1^{\text {st }}$ AND $2^{\text {nd }}$ ACCREDITATION LEVEL
}

\author{
Drapinska L. M. \\ Postgraduate Student at the Department of Fitness and Recreation \\ Lviv State University of Physical Culture named after Ivan Boberskyj \\ Tadeusz Kosciuszko str., 11, Lviv, Ukraine \\ orcid.org/0000-0001-6470-4849 \\ shypkalyudmila@ukr.net
}

Key words: physical education, education process, shaping, female students, motivation.

\begin{abstract}
The article proves that physical education in higher education institutions of I-II levels of accreditation does not fulfill its functions and requires the search for new non-traditional means and scientifically sound ways to improve the educational process. All this leads to a study that involves the search for new ways to improve the process of physical education of female students, based on popular types of physical activity. New non-traditional tools and methods can help increase interest in exercise. The purpose of the research is to increase the efficiency of physical training of female students in higher education establishments of Ukraine of the 1 st ad 2 nd accreditation level by using shaping technologies in physical training classes. Material and methods. To solve the tasks of the research, the author used the sociological method of polling of female students by way of the questionnaire survey and methods of mathematical statistics. Researches were carried out in the Technological College of Lviv Polytechnic National University and involved 40 secondyear female students. Results. As a result of our researches, it was proved that the use of the program of physical training of female students in higher education establishments of the 1 st ad 2nd accreditation level involving shaping technologies allows to achieve the positive effect in formation of interest of college female students to the psychical training classes. The study confirmed that female students prefer to choose the type of physical exercises for trainings and that the musical accompaniment of physical exercises is important. It was established that the main motivational factor stimulating female students to train is the possibility to have a beautiful trained body, to derive pleasure from physical exercises and to improve health. One of the reasons for the negative attitude of female students to the physical training is the low emotional background of classes and absence of possibility to choose the type of physical activity based on one's own preferences. It was proved that introducing of shaping classes into the program of physical training fostered the essential increase of interest of female students to the physical training. Conclusion. Increase motivation to engage in physical exercises in physical education classes can contribute to unconventional means and methods.
\end{abstract}

Постановка проблеми. Результати досліджень фахівців $[1 ; 11 ; 13$ та ін.] доводять, що для забезпечення повноцінного фізичного розвитку людини та збереження високого рівня іï працездатності впродовж всього життя необхідно систематично займатися фізичними вправами. Проте одне лиш усвідомлення цього факту не спонукає до систематичної рухової активності. У реальній дійсності ми спостерігаємо ігнорування навіть обов'язкових занять 3 фізичного виховання студентами закладів вищої освіти [7; 13 та ін.].
Однією із причин негативного ставлення студентів до фізичного виховання є низький емоційний фон занять та відсутність можливості вибирати вид рухової активності за вподобанням. Отже, традиційне фізичне виховання стикається з розбалансованістю потреб і мотивів студентів до систематичних занять фізичними вправами. Наукові дослідження останніх років свідчать, що застосування інноваційних форм занять та надання студентам можливості обирати види рухової активності за вподобаннями дозволяє підви- 
щити рівень фізичної підготовленості студентів та відвідуваність занять із фізичного виховання. Фахівці вказують на незначну ефективність традиційних форм занять у зміцненні здоров'я студентів та їх підготовці до професійної діяльності. Фізичне виховання не виконує свої функції і потребує пошуку нових нетрадиційних засобів i науково обгрунтованих шляхів удосконалення навчального процесу. Все це зумовлює своєчасність і актуальність проведення дослідження, що передбачає пошук нових засобів удосконалення процесу фізичного виховання студенток закладів вищої освіти, що базується на популярних видах рухової активності. Підвищенню мотивації до занять фізичними вправами можуть сприяти нетрадиційні засоби і методи. Одним 3 таких засобів може бути шейпінг $[3 ; 4 ; 5 ; 6 ; 9 ; 10 ; 14$ та ін.]. Цей різновид оздоровчих видів гімнастики має за мету фізичну досконалість, естетичну фігуру, гарну ходу, граціозну поставу - все те, про що мріє більшість студенток.

Робоча гіпотеза полягала у припущенні, що застосування шейпінг-технологій буде сприяти підвищенню зацікавленості студенток закладів вищої освіти I-II рівнів акредитації до систематичних занять фізичними вправами у навчальній формі занять.

Мета дослідження - підвищити ефективність фізичного виховання студенток закладів вищої освіти України I-II рівнів акредитації шляхом застосування шейпінг-технологій у навчальній формі занять 3 фізичного виховання.

Для вирішення завдань були застосовані такі методи: теоретичні - для аналізу і узагальнення даних науково-методичної літератури; соціологічні - для вивчення зацікавленості студентської молоді до фізичних вправ; методи математичної статистики - для обробки результатів дослідження.

Організація дослідження. Із метою вивчення можливості застосування шейпінгу у фізичному вихованні студенток закладів вищої освіти I-II рівнів акредитації, а також отримання інформації про кількісні і якісні зміни фізіологічних та соматичних показників при застосуванні шейпінг-технологій в навчальній формі занять із фізичного виховання ми провели порівняльний педагогічний експеримент. Дослідження було проведено у 2016-2017 н.р. і організовано на базі Відокремленого структурного підрозділу Технологічного коледжу Національного університету «Львівська політехніка». У процесі експерименту було проведено соціологічне дослідження шляхом анкетного опитування студенток. Опитування проводилося за допомогою розробленої нами анкети 3 метою вивчення ставлення студенток до занять фізичними вправами. У дослідженні взяли участь
40 студенток 2-го курсу навчання, які склали експериментальну групу.

Під час розроблення анкет були враховані основні методичні вказівки фахівців у даній галузі науки та принцип почергового застосування складних запитань 3 відносно простими. Застосовувалися закриті запитання, запитання-меню (ранжування) та інтервальна шкала. За рахунок цього було знижено ймовірність механічних та стереотипних відповідей. Для зручності опрацювання анкети були зашифровані.

Анкета для опитування студенток експериментальної групи, які відвідували заняття шейпінгом під час академічних занять із фізичного виховання, складалася 37 запитань, що безпосередньо стосувалися ставлення студенток до фізичної культури в цілому та до навчальної форми занять 3 фізичного виховання зокрема. У першому та 3 третього по шосте запитання передбачено три відповіді: «так» або «ні» і проміжні відповіді: «можливо» $(1,3,4$ та 6-те запитання) та «все одно» (5-те запитання). Оцінка відповідей на ці запитання анкети проведена у відсотках. У другому запитанні респондентки повинні були обрати три основні мотиви, що спонукають їх відвідувати заняття 3 фізичного виховання і пронумерувати вибрані відповіді цифрами 1, 2, 3 в порядку значущості для них. Відповіді на це запитання згруповані за ранжиром: за позначку «1» нараховано 3 бали, за «2» - 2 і за «3»»- один бал. Оцінка відповідей на ці запитання анкети здійснена за рейтингом. На сьоме запитання анкети «Наскільки Вам цікаво відвідувати заняття 3 фізичного виховання у ВНЗ?», складене за інтервальною шкалою, респондентки повинні були обрати і відзначити лише одну цифру або напис на шкалі, які відповідають рівню їх зацікавленості до відвідування занять 3 фізичного виховання у закладі вищої освіти. Відповіді згруповані у три рівні зацікавленості: від «зовсім не цікаво» до 30\% - низький рівень; 40\% $60 \%$ - середній і від 70\% до «дуже цікаво» - високий рівень.

Результати дослідження та їх обговорення. Зіставлення відповідей студенток експериментальної групи, які займалися шейпінгом під час академічних занять із фізичного виховання, на перше запитання «Чи хотіли б Ви обирати вид фізичних вправ для занять 3 фізичного виховання?» свідчить, що на початку експерименту 55\% респондентів дали ствердну відповідь, тоді як наприкінці експерименту таких відповідей було $85 \%$. Водночас $25 \%$ на початку та $15 \%$ наприкінці досліджень сумнівалися у своїх твердженнях, надавши перевагу відповіді «можливо». Натомість зовсім відсутні відповіді «ні» наприкінці експерименту при 20\% ствердних відповідях на початку експерименту. На нашу думку, це свідчення 
уподобання студентками занять шейпінгом у процесі організації занять 3 фізичного виховання та підтвердження досліджень фахівців [3; 10; 13 та ін.] про необхідність перегляду навчальних програм 3 фізичного вихованя для закладів вищої освіти щодо надання студентам можливості обирати вид фізичних вправ на академічних заняттях з фізичного виховання.

Результатами відповідей на запитання «Що спонукає Вас відвідувати заняття 3 фізичного виховання?» ми хотіли сформувати уяву про мотиви сучасної молоді до навчальної форми занять з фізичного виховання на даний час (рис. 1).

На початку експерименту спостерігаємо суттєву перевагу в прагненні студенток відвідувати заняття 3 фізичного виховання через потребу отримання заліку з даного предмету (98 балів). Наступними за значущістю стали турбота про власне здоров'я (58 балів) та бажання побудови гарної статури (24 бали). Інші мотиви або зовсім відсутні, або відзначені декількома учасницями із 40 респондентів у другу чи третю чергу за значущістю для них: можливість переключитися на інший вид діяльності (12 балів); прагнення особистої фізичної досконалості (10 балів) та можливість розвитку фізичних якостей (8 балів). Наші дослідження підтверджують дослідження низки фахівців [2; 3; 7 та ін.] про невдоволення студентами змістом навчаль- них програм з фізичного виховання, які спрямовані на розвиток фізичних якостей 3 метою успішної здачі Державних тестів і нормативів фізичної підготовленості населення України.

Аналізуючи результати дослідження наприкінці експерименту спостерігаємо переважне бажання продовжувати відвідувати заняття 3 фізичного виховання через можливість побудови гарної фігури (71 бал) та відчуття задоволення від фізичних вправ (70 балів). На третій - четвертій позиції (по 34 бали) є мотиви щодо можливості зміцнення здоров'я та потреба здачі заліку 3 фізичного виховання.

Важливо відзначити, що поліпшили свій рейтинг і більш другорядні мотиви, такі як «прагнення особистої фізичної досконалості» (поліпшення 3 10 до 16 балів) та «можливість переключитися на інший вид діяльності (поліпшення 312 до 15 балів).

Зовсім відсутні мотиви щодо можливості розвитку фізичних якостей (сила, бистрість, витривалість тощо). Наші дослідження підтверджують думку фахівців $[3 ; 4 ; 10]$ про позитивний вплив занять шейпінгом на корекцію форм статури, розвиток фізичних якостей і про збалансований розподіл навантажень на різні життєво важливі системи організму людини.

Спостерігаємо значний прогрес у результатах відповідей на запитання «Чи хотіли б Ви,

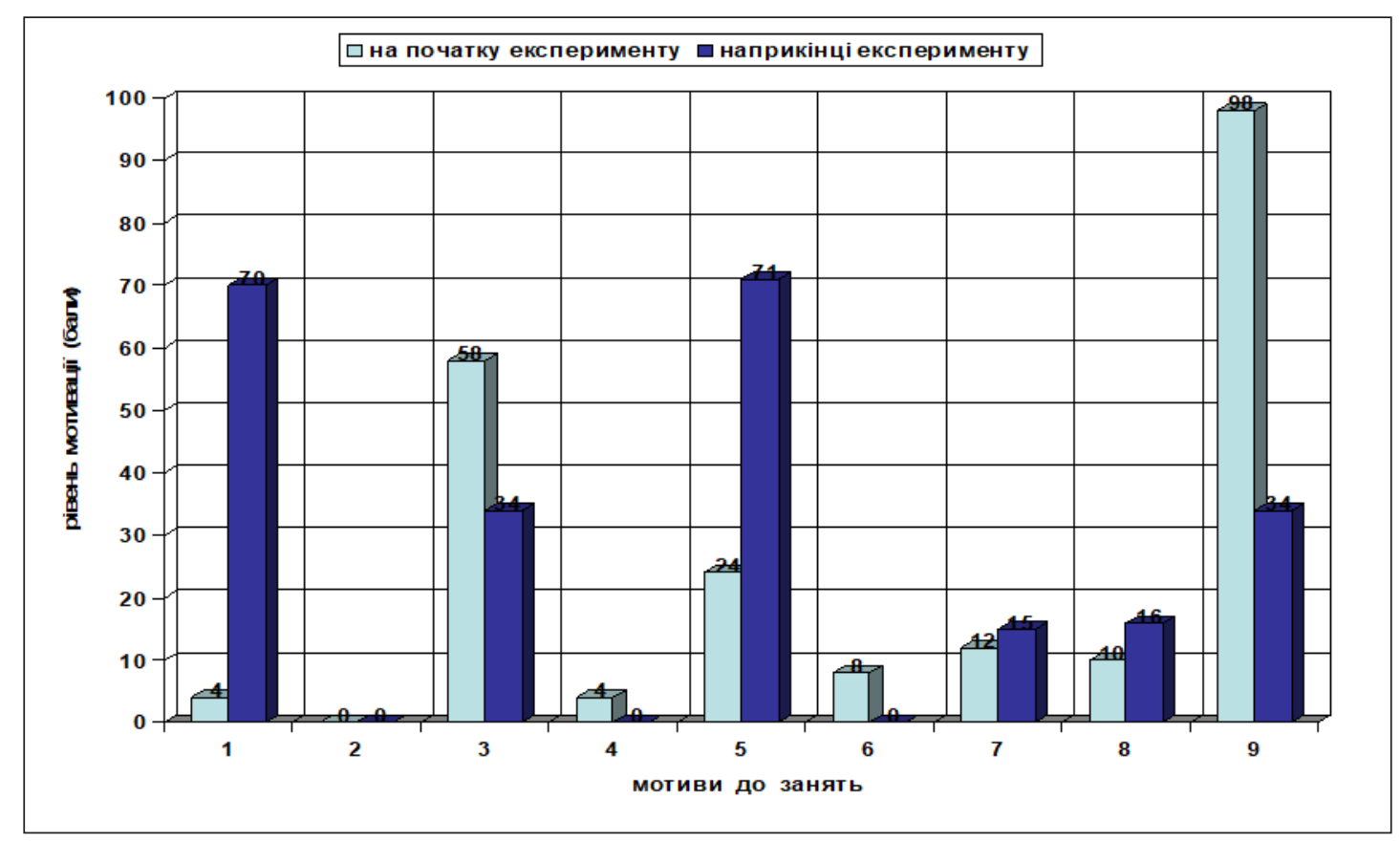

Рис. 1. *Мотиви, що спонукають студенток до занять 3 фізичного виховання $(\mathrm{n}=40)$

Примітки: *1 - відчуття задоволення від фізичних вправ; 2 - виховання психічних якостей (сила волі, наполегливість, тощо); 3 -можливість зміцнення здоров'я; 4-можливість отримати знання про фізичну культуру; 5 -можливість побудови гарної фігури; 6-можливість розвитку фізичних якостей (сила, бистрість, витривалість тощь); 7 - можливість переключитися на інший вид діяльності; 8 - прагнення особистої фізичної досконалості; 9 - потреба здачі заліку з фізичного виховання. 
щоб заняття 3 фізичного виховання сприяли покращенню Вашої статури?». Якщо на початку експерименту переважна більшість респонденток нічого не знали про систему шейпінг і не займалися шейпінгом на дозвіллі, то про це свідчать і результати відповідей на поставлене запитання. Ствердну відповідь «так» надали $25 \%$ опитуваних i $75 \%$ поставили позначку проти відповіді «можливо». Жодна 3 учасниць не відмітила позначку «ні». Після того, як студентки упродовж навчального року займалися шейпінгом згідно авторської Програми фізичного виховання студенток закладів вищої освіти I-II рівнів акредитації 3 використанням шейпінг-технологій, відповіді від сумніву змістилися у ствердні щодо можливостей покращення параметрів власної статури. Ствердно «так» відповіло 80\% респонденток, а «можливо» - 20\%. Як на початку досліджень, так і наприкінці, відповідей «ні» не було. На нашу думку, об'єктивність результатів цих досліджень підтверджують результати антропометричних вимірів параметрів статури дівчат, які були проведені дослідником у процесі проведення порівняльного педагогічного експерименту. Середньогруповий антропометричний рейтинг фігури 15 студенток експериментальної групи, які добровільно погодилися пройти виміри параметрів своєї фігури на початку та наприкінці навчального року, достовірно $(\mathrm{p}<0,05)$ поліпшився $з$ 45,7\% на початку до 65,7\% наприкінці експерименту. Вплив занять шейпінгом на зміни параметрів статури очевидний. Хоч у дослідженнях змін параметрів i форм статури прийняли участь 15 студенток із 40, які склали експериментальну групу, результати дослідження вплинули на бажання більшості студенток щодо вибору виду фізичних вправ у заняттях із фізичного виховання $з$ можливістю корекції форм статури.

Менш оптимістичні думки студенток щодо відповідей на запитання «Чи вважаєте Ви, що Вашу статуру можна покращити, відвідуючи заняття 3 фізичного виховання у навчальному закладі?». На початку експерименту 77,5\% дали негативну відповідь «ні» і 12,5\% відповіли «можливо». Лиш 10\% респондентів допускали таку можливість. Натомість наприкінці експерименту переконливо «ні» висловили 12,5\% дівчат, ще 22,5\% продовжили сумніватися у таких можливостях та 65\% висловили чітке переконання в тому, що в результаті застосування шейпінг-технологій в навчальній формі занять із фізичного виховання можна покращити власну статуру. Отримані результати підтверджують дослідження Шевців Уляни (2009) та Гумена Василя (2016) щодо позитивного впливу занять шейпінгом на корекцію форм статури.
За результатами відповідей на запитання «Чи подобається Вам виконувати фізичні вправи під музичний супровід?» ми хотіли сформувати уяву про уподобання студенток до виконання фізичних вправ 3 використанням музичного супроводу. На початку експерименту кожна четверта респондентка (25\%) висловила негативне ставлення до даної проблеми. Наступні відповіді розділилися навпіл: 37,5\% відповідей було «так», і стільки ж - «все одно». Наприкінці експерименту 87,5\% респондентів відповіли «так», і 12,5\% - «все одно». Відповідей «ні» не було. На нашу думку, це результат впливу занять шейпінгом, оскільки вправи в шейпінг-технологіях записані на відеоносіях із використанням музичного супроводу. Як підтверджують результати наших досліджень, дівчатам до вподоби такі заняття. Наші результати погоджуються з думкою інших фахівців [3; 8; 9 та iн.] щодо позитивного впливу музичного супроводу фізичних вправ на відвідуваність занять.

Підтвердженням уподобання та інтересу щодо занять шейпінгом дали результати відповідей на запитання «Чи сподіваєтеся Ви продовжувати заняття фізичними вправами на дозвіллі, коли фізичне виховання не буде обов'язковим як навчальна дисципліна?». 57,5\% - «ні», 25\% «можливо» і 17,5\% - «так». Такими відповідями на початку експерименту студентки коледжу показали особистий рівень ставлення дівчат до фізичних вправ та розуміння важливості рухового діапазону у веденні здорового способу життя. Відвідуючи заняття з фізичного виховання з використанням шейпінг-технологій, ставлення до важливості фізичних вправ у своєму подальшому житті суттєво покращилося. Натомість 70\% респонденток дали ствердну відповідь, 17,5\% допускають таку можливість і 12,5\% залишились переконаними в тому, що займатися фізичними вправами в подальшому житті їм не потрібно. Наші дослідження підтверджують думку фахівців $[2 ; 3 ; 7$ та iн.] про те, що відсутність у студентів можливості обрати за уподобанням вид фізичних вправ на заняттях 3 фізичного виховання негативно впливає на їх розуміння важливості виконання фізичних вправ на дозвіллі та потреби вести здоровий спосіб життя.

Аналіз відповідей на запитання «Наскільки Вам цікаво відвідувати заняття з фізичного виховання у вищому навчальному закладі?» показує, що на початку експерименту для переважної більшості студенток заняття з фізичного виховання за чинною програмою, згідно якої вони займалися на першому курсі навчання, не викликали особливого інтересу. Для 22 студенток рівень зацікавленості відповідав низькому рівневі, ще 10 студенток - середньому і лише у двох студенток рівень зацікавленості був високим (рис. 2). 


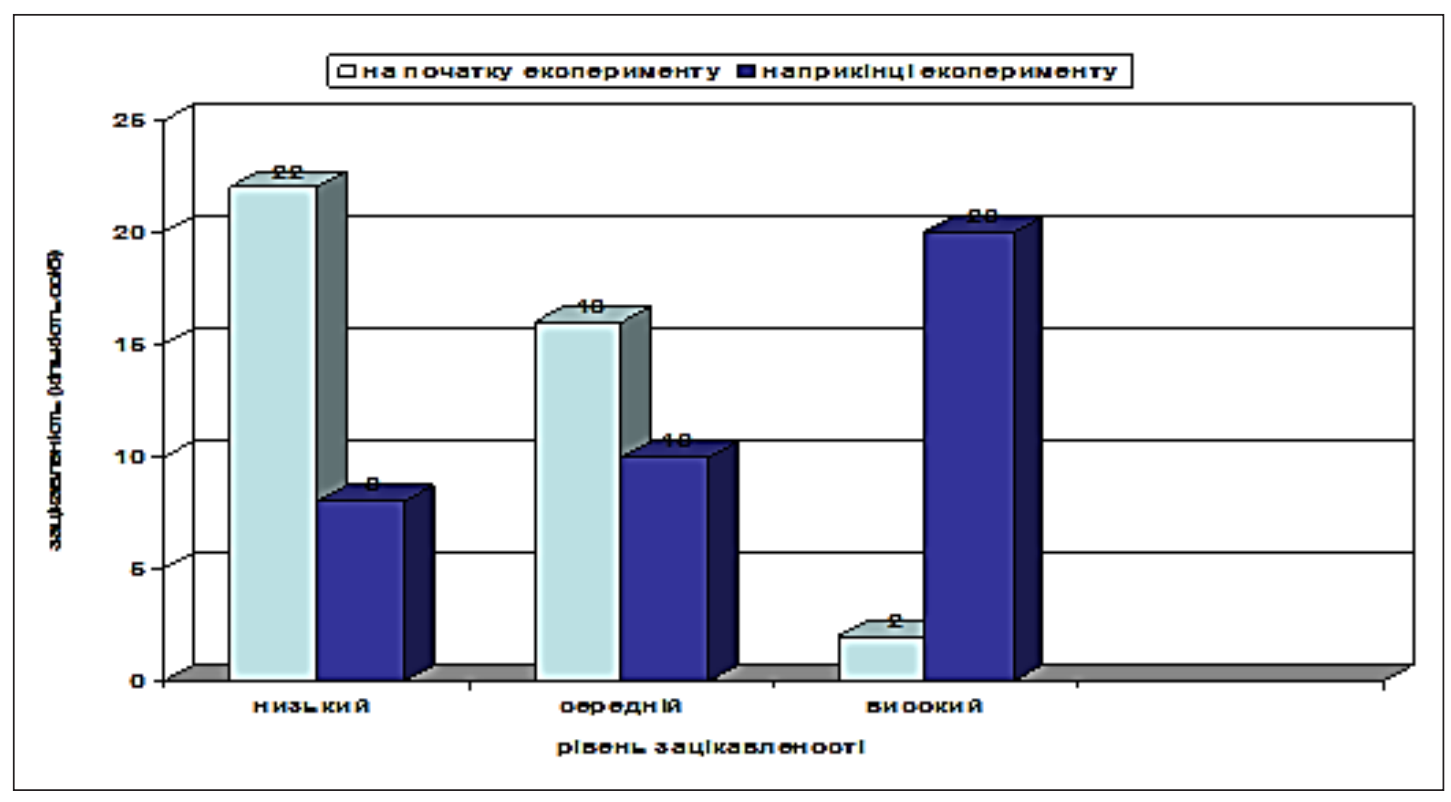

Рис. 2. Зацікавленість студенток до занять 3 фізичного виховання у закладах вищої освіти I-II рівнів акредитації (n=40)

Заняття шейпінгом упродовж тривалості педагогічного експерименту вплинуло на зміни зацікавленості дівчат до навчальних занять 3 фізичного виховання. Про низький рівень зацікавленості висловилися 8 учасниць (20\%).

Ще 12 відповідей респонденток (30\%) відповідають середньому рівневі зацікавленості, а 20 осіб (50\%) відзначили високий рівень зацікавленості до відвідування занять 3 фізичного виховання. Отримані результати переконливо свідчать, що заняття шейпінгом під час академічних занять i3 фізичного виховання сприяли значному зростанню зацікавленості студенток до рухової активності. Наші дані підтверджують дослідження низки авторів про зростання зацікавленості студенток до нетрадиційних видів фізичних вправ [3; $10 ; 13$ та ін.].

Обговорення результатів дослідження. Функції фізичного виховання у закладах вищої освіти реалізуються через систему навчальних $\mathrm{i}$ позанавчальних занять, через залучення студентської молоді до систематичних занять спортом та організації спортивно-оздоровчих занять на дозвіллі. Як навчальна дисципліна фізичне виховання повинно відповідати певним програмно-нормативним вимогам. Аналіз даних науково-методичної літератури дає підстави стверджувати, що в умовах трансформації вищої освіти в Україні проблема реформування фізичного виховання у закладах вищої освіти залишається однією 3 найважливіших. Навчальна форма занять із фізичного виховання потребує змін щодо ефективності цих занять Навчальні програми не враховують індивідуальних можливостей організму і бажання студентів виконувати фізичні вправи. Фахівці вказують на необхідність пошуку та впровадження у процес фізичного виховання нових та нетрадиційних підходів щодо організації занять 3 фізичного виховання $[2 ; 3 ; 10$ та ін.]. Наші попередні дослідження $[4 ; 5]$ також підтверджують думку про негативне ставлення студенток до чинної програми $з$ фізичного виховання та необхідності змін нормативно-правової бази навчального процесу закладів вищої освіти України.

У процесі порівняльного педагогічного експерименту на предмет впровадження шейпінг-технологій у навчальний процес студенток закладів вищої освіти I-II рівнів акредитації було проведено опитування студенток експериментальної групи 3 метою з'ясувати ставлення студенток до вибору фізичних вправ для занять та встановити мотиви ставлення студенток до різновиду фізичних вправ у процесі навчальної форми занять. Аналіз результатів дослідження дає підстави стверджувати, що дівчатам старшого підліткового віку подобається займатися нетрадиційними видами гімнастики. Основними мотивами, які спонукають дівчат відвідувати заняття, є прагнення корекції власної статури, відчуття задоволення від фізичних вправ та зміцнення здоров'я. Водночас на початку експерименту мотиви у дівчат були дещо іншими. Так, на перше місце студентки поставили потребу отримання заліку з фізичного виховання. Наступними за значущістю стали турбота про власне здоров'я та бажання побудови гарної статури. Наші дослідження підтверджують:

1) дані фахівців Р. Сіренко (2005), I. Боднар (2012), В. Гумена (2016), С. Федотенко (2017) та 
інші - те, що чинні вимоги навчальних програм у системі освіти не сприяють інтересу до навчальної форми занять у навчальних закладах та поліпшенню їх відвідуваності;

2) дані фахівців У. Шевців (2009), В. Гумена (2016), А. Вільчковської (2019) - те, що музичний супровід фізичних вправ $є$ одним із ефективних засобів стимулювання студенток до відвідування занять фізичними вправами;

3) дані В. Гумена (2016) - доцільність застосування елементів новітніх шейпінг-технологій у навчальній формі занять із фізичного виховання в закладах вищої освіти, додатково модифікуючи їх згідно з вимогами навчальних програм;

4) дані фахівців Слюсарчук В. (2019), Федотенко C. (2017), Goncharenko, M. \& Parfinenko, T. (2019), Pantik, V. (2018), Vernegaard, K. (2017) та інші - необхідність перегляду навчальних програм 3 фізичного вихованя для закладів вищої освіти щодо надання студентам можливості обирати вид фізичних вправ на академічних заняттях iз фізичного виховання;

5) дані У. Шевців (2009) та В. Гумена (2016) позитивний вплив занять шейпінгом на формування фігури жінок і збалансований розподіл навантажень на різні життєво важливі системи організму людини;

6) дані Т. Круцевич, Ж. Малахової (2018) - те, що незначна кількість студентів надають перевагу навчальним заняттямі з фізичного виховання, що дає привід оптимізувати саму цю форму організації занять і підтримати розвиток самостійної форми організації фізичного виховання.

Висновки. Результати опитування студенток свідчать про те, що традиційні заняття з фізичного виховання у закладах вищої освіти I-II рівнів акредитації за чинною програмою не сприяють формуванню в них зацікавленості до продовження занять фізичними вправами після закінчення терміну обов'язкового відвідування зазначених занять.

Використання шейпінг-технологій S3 музичним супроводом занять сприяє підвищенню зацікавленості студенток до навчальної та позанавчальної форм занять s3 фізичного виховання.

Пsl xfc складаннz навчальних програм s3 фізичного виховання у вищій школі і виборі засобів необхідно зважати на те, що головними мотивами, що спонукають дівчат до занять фізичними вправами, є прагнення побудови гарної статури та можливість зміцнення здоров'я.

Перспективи подальших досліджень. Експериментально доведена ефективність Програми фізичного виховання студенток закладів вищої освіти I-II рівнів акредитації 3 використанням шейпінг-технологій дає підстави рекомендувати ㄲi для застосування в навчальній та позанавчальній формах занять у закладах вищої освіти I-II рівнів акредитації.

\section{ЛІТЕРАТУРА}

1. Амосов М. М. Роздуми про здоро'я. Київ : Здоров'я. 1990. 168 с.

2. Боднар І. Актуальні проблеми процесу фізичного виховання студентів. Фізична активність, здоров’я і спорт. 2012. № 3. С. 10-15.

3. Гумен В. Шейпінг в системі фізичного виховання вищих навчальних закладів : монографія. Львів : ЛДУФК, 2016. 227 с.

4. Драпінська Л., Шевців У., Семаль Н. Особливості використання шейпінгу у фізичному вихованні студентської молоді. Спортивна наука України. Львів : ЛДУФК, 2016. № 6. С. 9-15. URL : http//sportscience.ldufk.edu.ua/index.php/snu.

5. Драпінська Людмила, Шевців Уляна, Гумен Василь. Соціальні аспекти розвитку шейпінгу в Україні. Фізична культура, спорт та здоров'я нації. Вінниця. 2018. Вип. 5(24). С. 454-459.

6. Драпінська Людмила, Шевців Уляна. Програма фізичного виховання студенток закладів вищої освіти I-II рівнів акредитації з використанням шейпінг-технологій. Молода спортивна наука Украӥни. Львів : ЛДУФК. 2019. Т. 2. С. 38-39.

7. Круцевич Тетяна. Малахова Жанна. Фізична підготовленість студентів у сучасних умовах навчання в медичних закладах вищої освіти. Спортивний вісник Придніпров'я : Дніпро : Інновація. 2018. № 2. С. 65-68.

8. Линець М., Гумен В., Гордійчук С. Шейпінг у системі фізичного виховання студенток. Теорія і методика фізичного виховання і спорту. 2002. № 2-3. С. 134-137.

9. Скидан Г., Савдалев С., Врублевський Є. Методична спрямованість фізкультурно-оздоровчих занять шейпінгом зі студентками. Фізична активність, здоров'я і спорт. 2013. № 4. С. 6572.

10. Шевців У.С. Технологія впровадження оздоровчих видів гімнастики у фізичне виховання старшокласниць (на прикладі шейпінгу) : дис. ... канд. наук з фіз. виховання і спорту : 24.00.02. Львів, 2009. 234 с.

11. Pantik, V. Структура та рівень рухової активності студентів закладів вищої освіти. Фізичне виховання, спорт і культура здоров'я у сучасному суспільстві. 2018. № 3(43). С. 99-107.

12. Sofi F., Capalbo A., Cesari F. [et. al.] (2008). Physical activity during leisure time and primary prevention of coronary heart disease: an updated meta-analysis of cohort studies. European journal of Cardiovascular Prevention \& Rehabilitation. Vol. 15. 247-257. 
13. Tsjovh L., Koryahin V., Blavt O. (2019) Implementation of innovative pedagogical technologies in the control of physical education of special medical groups. Journal of Kamenetz-Podolsk national University named after Ivan Ogienko. Physical education, sport and human health. Issue 14. 5-9.

14. Vilchkovska A. Особливості інтеграції музики й рухової діяльності школярів у процесі фізичного виховання. Фізичне виховання, спорт і культура здоров'я у сучасному суспільстві. 2019. № 3(47). C. $10-16$.

\section{REFERENCES}

1. Amosov M. M. (1990). Rozdumy pro zdorovya [Reflections on health]. K. : Zdorovya. 168 p. [in Ukrainian].

2. Bodnar I. (2012). Aktual'ni problemy procesu fizychnogo vykhovannia studentiv [Actual problems of process of physical education students]. Physical activity, health and sport. \#3. P. 10-15.

3. Gumen V. (2016). Sheyping v systemi fizychnogo vykhovannya vyshchykh navchaljnykh zakladiv : monografiya [Shaping in the system of physical education of higher educational institutions : monograph] / Vasyl' Gumen. Lviv : LDUFK. 227 p. [in Ukrainian].

4. Drapinska L., Shevtsiv U., Semal' N. (2016). Osoblyvosti vykorystannya sheypingu u fizychnomu vykhovanni students'koyi molodi [The features of the shaping in the physical education of student youth]. Sports science of Ukraine. Lviv : LDUFK. \#6. P. 9-15. URL : http//sportscience.ldufk.edu.ua/index.php/snu

5. Drapinska Lyudmila, Shevtsiv Ulyana, Gumen Vasyl' (2018). Social'ni aspecty rozvytku sheypingu $\mathrm{v}$ Ukrayini [Social aspects of the development of the shaping in Ukraine]. Physical culture, sport and nation's health. Vinnycya. \#5(24). P. 454-459.

6. Drapinska Lyudmila, Shevciv Ulyana (2019). Programa fizychnogo vykhovannja studentok zakladiv vyshchoji osvity I-II rivniv akredytawiji z vykorystannjam shejping-tekhnologij [Program of physical training of female students of higher education institutions of the $1^{\text {st }}$ and $2^{\text {nd }}$ accreditation levels with the use of shaping technologies]. Young sport science of Ukraine. Lviv : LDUFK. T. 2. 38-39. [in Ukrainian].

7. Krutsevych Tetiana, Malakhova Zhanna. (2018). Fizychna pidhotovlenistj studentiv u suchasnykh umovakh navchannja $\mathrm{v}$ medychnykh zakladakh vyshchoji osvity [Physical training of students in the current conditions of education at higher medical education institutions]. Sportyvnyi visnyk Prydniprovia. \#2. P. 65-68. [in Ukrainian].

8. Lynetsj M., Gumen V., Gordijchuk S. (2002). Shejping u systemi fizychnogo vykhovannja studentok [Shaping in the system of physical training of female students]. Theory and methods of physical education and sport. \#2-3. P. 134-137. [in Ukrainian].

9. Skydan G., Savdalev S., Vrublevs'kyi Ye. (2013). Metodychna spryamovanist' fizkul'turno-ozdorovchykh zanyat' sheypingom zi studentkamy [Methodological orientation of shaping exercises for female students]. Physical activity, health and sport. \#4. P. 65-72. [in Ukrainian].

10. Shevtsiv U. S. (2009). Tekhnologija vprovadzhennja ozdorovchykh vydiv gimnastyky u fizychne vykhovannja ctarshoklasnycj (na prykladi shejpingu) [Technology of introduction of recreational types of gymnastics into the program of physical training (using shaping as an example)] : dys....kand. nauk z fiz. vykhovannja i sportu : 24.00.02. Lviv. 234 p. [in Ukrainian]

11. Pantik, V. (2018).Struktura ta riven'rukhovoyi aktyvnosti studentiv zakladiv vyshchoyi osvity [The structure and level of psychical activity of students of higher education establishments]. Physical education, sport and health culture in modern society. \#3 (43), 99-107. https://doi.org/10.29038/2220-7481-2 018-03-99-107 [in Ukrainian].

12. Sofi F., Capalbo A., Cesari F. [et. al.] (2008). Physical activity during leisure time and primary prevention of coronary heart disease: an updated meta-analysis of cohort studies. European journal of Cardiovascular Prevention \& Rehabilitation. Vol. 15. 247-257.

13. Tsjovh L., Koryahin V., Blavt O. (2019) Implementation of innovative pedagogical technologies in the control of physical education of special medical groups. Journal of Kamenetz-Podolsk national University named after Ivan Ogienko. Physical education, sport and human health. Issue 14. 5-9.

14. Vilchkovska A. (2019). Osoblyvosti integraciyi muzyky y rukhovoyi siyal'nosti shkolyariv u procesi fizychnogo vykhovannya [Features integration of music and motor activities of pupils in physical education]. Physical education, sport and health culture in modern society. \#3(47), 10-16. https://doi.org/10.2 9038/2220-7481-2019-03-10-16. 